\title{
Georgenia satyanarayanai sp. nov., an alkaliphilic and thermotolerant amylase-producing actinobacterium isolated from a soda lake
}

\author{
Correspondence \\ Ch. Sasikala \\ r449@sify.com or sasi449@ \\ yahoo.ie
}

\author{
A. Srinivas, ${ }^{1}$ K. Rahul, ${ }^{1}$ Ch. Sasikala, ${ }^{1}$ Y. Subhash, ${ }^{2}$ E. V. V. Ramaprasad ${ }^{1}$ \\ and Ch. V. Ramana ${ }^{2}$ \\ ${ }^{1}$ Bacterial Discovery Laboratory, Centre for Environment, Institute of Science and Technology, \\ J.N.T. University Hyderabad, Kukatpally, Hyderabad 500 085, India \\ ${ }^{2}$ Department of Plant Sciences, School of Life Sciences, University of Hyderabad, \\ PO Central University, Hyderabad 500 046, India
}

\begin{abstract}
A Gram-stain-positive, oxidase-negative, starch-hydrolysing, actinobacterium (strain $J \mathrm{C}^{2} 2^{\top}$ ) was isolated from a soda lake in Lonar, India. Based on 16S rRNA gene sequence similarity studies, strain $\mathrm{JC} 82^{\top}$ belonged to the genus Georgenia and was most closely related to Georgenia muralis $1 \mathrm{~A}-\mathrm{C}^{\top}(96.8 \%)$ and other members of the genus Georgenia $(<96.5 \%)$. The DNA G+C content of strain $\mathrm{JC} 82^{\top}$ was $73.4 \mathrm{~mol} \%$. The cell-wall amino acids were alanine, glutamic acid and lysine with peptidoglycan type A4 $\alpha$. Polar lipids included diphosphatidylglycerol, phosphatidylglycerol, phosphatidylinositol, phosphatidylinositol mannosides, an unidentified lipid (L1) and an unidentified glycolipid (GL3). The predominant isoprenoid quinone was menaquinone $\mathrm{MK}-8\left(\mathrm{H}_{4}\right)$. Anteiso- $\mathrm{C}_{15 \text { :0 }}$ was the predominant fatty acid and significant proportions of iso- $\mathrm{C}_{14: 0}, \mathrm{C}_{14: 0}$, $\mathrm{C}_{16: 0}$, iso- $\mathrm{C}_{15: 0}$ and iso- $\mathrm{C}_{16: 0}$ were also detected. Strain $\mathrm{JC} 82^{\top}$ produced thermostable alkaline amylase. The results of physiological and biochemical tests allowed a clear phenotypic differentiation of strain $\mathrm{JC} 82^{\top}$ from all other members of the genus Georgenia. Based on these data, strain $\mathrm{JC} 82^{\top}$ represents a novel species of the genus Georgenia, for which the name Georgenia satyanarayanai sp. nov. is proposed. The type strain is $\mathrm{JC} 2^{\top}\left(=\mathrm{KCTC} 19802^{\top}\right.$ $=$ NBRC $107612^{\top}$ ).
\end{abstract}

The alkaline Lonar Lake ( $\left.19^{\circ} 58^{\prime} 36^{\prime \prime} \mathrm{N}, 76^{\circ} 30^{\prime} 30^{\prime \prime} \mathrm{E}\right)$ in India is a unique basaltic rock meteorite impact crater, ranking third in the world in terms of alkalinity. The lake is rich in bacterial diversity (Joshi et al., 2008; Wani et al., 2006), although at the time of writing, only two bacterial species isolated from the lake had validly published names (Indibacter alkaliphilus and Nitritalea halalkaliphila; Anil Kumar et al., 2010a, b). In this report, we describe a novel actinobacterium, strain $\mathrm{JC}^{\mathrm{T}}{ }^{\mathrm{T}}$ belonging to the genus Georgenia which was isolated from a sediment sample from Lonar Lake. The genus Georgenia was first proposed by Altenburger et al. (2002) with Georgenia muralis as the type species. At the time of writing, the genus Georgenia comprised six recognized species, including the recently described Georgenia daeguensis (Woo et al., 2012). The members of this genus are Gram-stainpositive, aerobic or facultative anaerobic, non-sporulating, oxidase- and catalase-positive, motile or non-motile bacteria

\section{Abbreviations: $\mathrm{ME}$, minimum-evolution; NJ, neighbour-joining.}

The GenBank/EMBL/DDBJ accession number for the 16S rRNA gene sequence of strain $\mathrm{JC}^{\mathrm{T}}{ }^{\top}$ is FN995635.

Four supplementary figures and a supplementary table are available with the online version of this paper. with $\mathrm{MK}-8(\mathrm{H} 4)$ as the predominant menaquinone, anteiso$\mathrm{C}_{15: 0}$ as the major fatty acid, lysine as the diagnostic cell wall amino acid and a polar lipid profile with diphosphatidylglycerol and phosphatidylglycerol as major components (Tang et al., 2010).

Strain $\mathrm{JC} 82^{\mathrm{T}}$ was isolated from a sediment sample collected from Lonar Lake in Maharashtra, India, using nutrient agar (Hi-Media) under aerobic conditions. Pure cultures were lyophilized and preserved at $4{ }^{\circ} \mathrm{C}$. Morphological properties such as cell shape, cell size and motility were observed by phase-contrast light microscopy (BH-2; Olympus). The $\mathrm{pH}$ and temperature ranges for growth were examined in nutrient broth. Salt tolerance tests were carried out in nutrient broth supplemented with varying concentrations of $\mathrm{NaCl}$. Growth was measured turbidometrically at $540 \mathrm{~nm}$ in a colorimeter (Systronics). Various biochemical tests such as hydrolysis of starch and gelatin, and chitinase, oxidase and catalase activities were carried out in media described by Cappuccino \& Sherman (1998). Other biochemical tests were performed using the GP2 MicroPlate (Biolog) according to the manufacturer's instructions. Georgenia muralis $1 \mathrm{~A}-\mathrm{C}^{\mathrm{T}}\left(=\mathrm{JCM} 12241^{\mathrm{T}}\right)$ and Georgenia soli CCNMPT-T3 $^{\mathrm{T}} \quad\left(=\mathrm{DSM} 21838^{\mathrm{T}}\right.$ ) (obtained from Dr C.-C. 
Young, National Chung Hsing University, Taiwan) were used for comparative taxonomic analysis throughout this study as recommended for minimum standards for description of new species (Tindall et al., 2010).

Fatty acids, quinones and polar lipids of the strains were analysed from cells grown in nutrient broth. Cells were harvested by centrifugation $\left(10000 \mathrm{~g}\right.$ for $15 \mathrm{~min}$ at $\left.4{ }^{\circ} \mathrm{C}\right)$ after reaching a cell density of $70 \%$ of the maximum optical density $\left(100 \%=0.8 \mathrm{OD}_{540}\right)$, and the lyophilized pellet was used for analysis. Cellular fatty acids were methylated, separated and identified according to the instructions for the Microbial Identification System [MIDI version 6.0; Microbial ID (Sasser, 1990)] which was outsourced through Royal Research Laboratories, Secunderabad, India.

Polar lipids were extracted from $1 \mathrm{~g}$ freeze-dried cells with methanol/chloroform/saline $(2: 1: 0.8$, by vol.) as described by Kates (1986). Lipids were separated by two-dimensional thin layer chromatography (TLC) using silica gel TLC plates (Kieselgel $60 \mathrm{~F}_{254}$; Merck) with chloroform/methanol/water $(75: 32: 4$, by vol.) in the first dimension and chloroform/methanol/acetic acid/water $(86: 16: 15: 4$, by vol.) in the second dimension (modified after Tindall, 1990a, b; Oren et al., 1996). Total polar lipid profiles were detected by spraying with $5 \%(\mathrm{v} / \mathrm{v})$ ethanolic molybdophosphoric acid and further characterized by spraying with ninhydrin (for amino groups), molybdenum blue (for phosphates), Dragendorff s reagent (for quaternary nitrogen) or $\alpha$-naphthol (for sugars) (Kates, 1972; Oren et al., 1996). Quinones were extracted with a chloroform/methanol $(2: 1, \mathrm{v} / \mathrm{v})$ mixture, purified by TLC and analysed by HPLC (Hiraishi \& Hoshino, 1984; Hiraishi et al., 1984).

The peptidoglycan of cells of strain $\mathrm{JC}^{2} 2^{\mathrm{T}}$ was isolated following disruption of the cells by shaking with glass beads and subsequent trypsin digestion, according to the method of Schleifer (1985). The cell wall was hydrolysed for amino acid analyses as described by Schleifer \& Kandler (1972). Amino acids in cell-wall hydrolysates were analysed by HPLC (Tang et al., 2009a, b; McKerrow et al., 2000).

For analysis of amylase activity bacterial strains were grown on starch $(2 \% \mathrm{w} / \mathrm{v})$ as sole source of carbon in a mineral medium which contained $\left(\mathrm{g} \mathrm{l}^{-1}\right): \mathrm{NH}_{4} \mathrm{Cl}(0.6) ; \mathrm{KH}_{2} \mathrm{PO}_{4}$ (0.5); $\mathrm{NaCl}(0.4) ; \mathrm{MgSO}_{4} \cdot 7 \mathrm{H}_{2} \mathrm{O}(0.24), \mathrm{CaCl}_{2}$ (0.05), and yeast extract $(0.3)$. Cells were harvested by centrifugation (10000 r.p.m. for $20 \mathrm{~min}$ at $4{ }^{\circ} \mathrm{C}$ ) after $48 \mathrm{~h}$ of growth, and the supernatant was used as a source for amylase. Ammonium sulphate was added to the supernatant to achieve $90 \%$ saturation, keeping $\mathrm{pH}$ at 7.0. Precipitated proteins were separated by centrifugation $(30000 \mathrm{~g}$ for $20 \mathrm{~min}$ ), resuspended in phosphate buffer ( $\mathrm{pH} \mathrm{7)}$ and dialysed against three changes of 31 of the same buffer for $3 \mathrm{~h}$ each. Amylase activity was determined by measuring the formation of reducing sugars (analysed according to Nelson, 1944) from starch (1\%) in a final volume of $0.5 \mathrm{ml}$ of an appropriate buffer $\left(\mathrm{K}_{2} \mathrm{HPO}_{4}-\mathrm{KH}_{2} \mathrm{PO}_{4}\right.$ buffer for pH 5-8; $\mathrm{NaHCO}_{3}-\mathrm{NaOH}$ buffer for $\mathrm{pH} 9-11$; and $\mathrm{NaCO}_{3}-$ $\mathrm{NaOH}$ buffer for $\mathrm{pH}$ 12). A unit (U) of amylase is defined as the amount of enzyme that released $1 \mu \mathrm{M} \mathrm{min}{ }^{-1}$ reducing sugars.

Genomic DNA was extracted and purified according to the method of Marmur (1961) and the G+C content (mol\%) of the DNA was determined by HPLC (Mesbah et al., 1989). Cell material for $16 \mathrm{~S}$ rRNA gene sequencing was taken from a single colony. DNA was extracted and purified by using a Qiagen genomic DNA extraction kit. Recombinant Taq polymerase (Genei) was used for PCR. The complete length of the 16S rRNA gene sequence was obtained by sequencing with primers, $\mathrm{F}^{\prime}-27$ (5'-GTTTGATCCTGGCTCAG-3'), and R'-1489 (5'-TACCTTGTTACGACTTCA-3') [corresponding to positions 11-27 and 1489-1506 for $\mathrm{F}^{\prime}-27$ and $\mathrm{R}^{\prime}-1489$, respectively, according to the Escherichia coli 16S rRNA numbering system of the International Union of Biochemistry (Brosius et al., 1978; Lane et al., 1985)]. PCR amplification was performed as described previously (Imhoff \& Pfennig, 2001; Imhoff et al., 1998 ) and 16S rRNA gene sequences were obtained by cycle sequencing with a SequiTherm sequencing kit (Biozym) and chain termination reaction (Sanger et al., 1977) using an automated laser fluorescence sequencer (Pharmacia). The identification of phylogenetic neighbours and calculation of pairwise 16S rRNA gene sequence similarity were achieved using the NCBI-BLAST search (Altschul et al., 1990) and EzTaxon server (Chun et al., 2007). The CLUSTAL $\mathrm{W}$ algorithm of MEGA 4 software was used for sequence alignments and MEGA 4 (Tamura et al., 2007) software was used for phylogenetic analysis of the individual sequences. Distances were calculated by using the Kimura correction in a pairwise deletion manner (Kimura, 1980). Neighbourjoining (NJ) and minimum evolution (ME) methods in the MEGA 4 software were used to construct phylogenetic trees. Percentage support values were obtained using a bootstrap procedure.

The genomic DNA G+C content of strain $\mathrm{JC}^{2} 2^{\mathrm{T}}$ was $73.4 \mathrm{~mol} \%$. The results of phylogenetic analysis of the $16 \mathrm{~S}$ rRNA gene sequence suggested that strain $\mathrm{JC}^{\mathrm{T}} 2^{\mathrm{T}}$ belonged to the genus Georgenia and was closely related to all recognised species of the genus Georgenia: G. muralis $1 \mathrm{~A}-\mathrm{C}^{\mathrm{T}}(96.3 \% 16 \mathrm{~S}$ rRNA gene sequence similarity), Georgenia thermotolerans TT02-04 ${ }^{\mathrm{T}}(96 \%)$, Georgenia daeguensis $2 \mathrm{C} 6-43^{\mathrm{T}}(96 \%), \mathrm{G}$. soli CC-NMPT-T3 ${ }^{\mathrm{T}}(95.9 \%)$, Georgenia ruanii YIM $004^{\mathrm{T}}$ $(95.9 \%)$ and Georgenia halophila YIM $93316^{\mathrm{T}}$ (95.4\%) (NJ tree is shown as Fig. 1 and ME tree is shown as Fig. S1, available in IJSEM online). Though strain $\mathrm{JC}^{2}{ }^{\mathrm{T}}$ shared relatively high sequence similarity with G. muralis $1 \mathrm{~A}-\mathrm{C}^{\mathrm{T}}$ and G. soli CC-NMPT-T3 ${ }^{\mathrm{T}}$, clustering occurred with $G$. halophila YIM $93316^{\mathrm{T}}$.

Colonies of strain $\mathrm{JC}^{\mathrm{T}} 2^{\mathrm{T}}$ grown on nutrient agar were bright yellow, circular (2-2.5 $\mathrm{mm}$ in diameter), convex with entire margin. Cells of strain $\mathrm{JC} 82^{\mathrm{T}}$ were ovoid to rodshaped, non-motile and $0.8-1.2 \mu \mathrm{m}$ in diameter. Lack of motility was also seen with $G$. muralis $1 \mathrm{~A}-\mathrm{C}^{\mathrm{T}}$, while $G$. soli CC-NMPT-T3 ${ }^{\mathrm{T}}$ cells were motile. Strain $\mathrm{JC} 82^{\mathrm{T}}$ grew over a $\mathrm{pH}$ range of 4-12 (optimum, 7-10). $\mathrm{NaCl}$ was not essential 


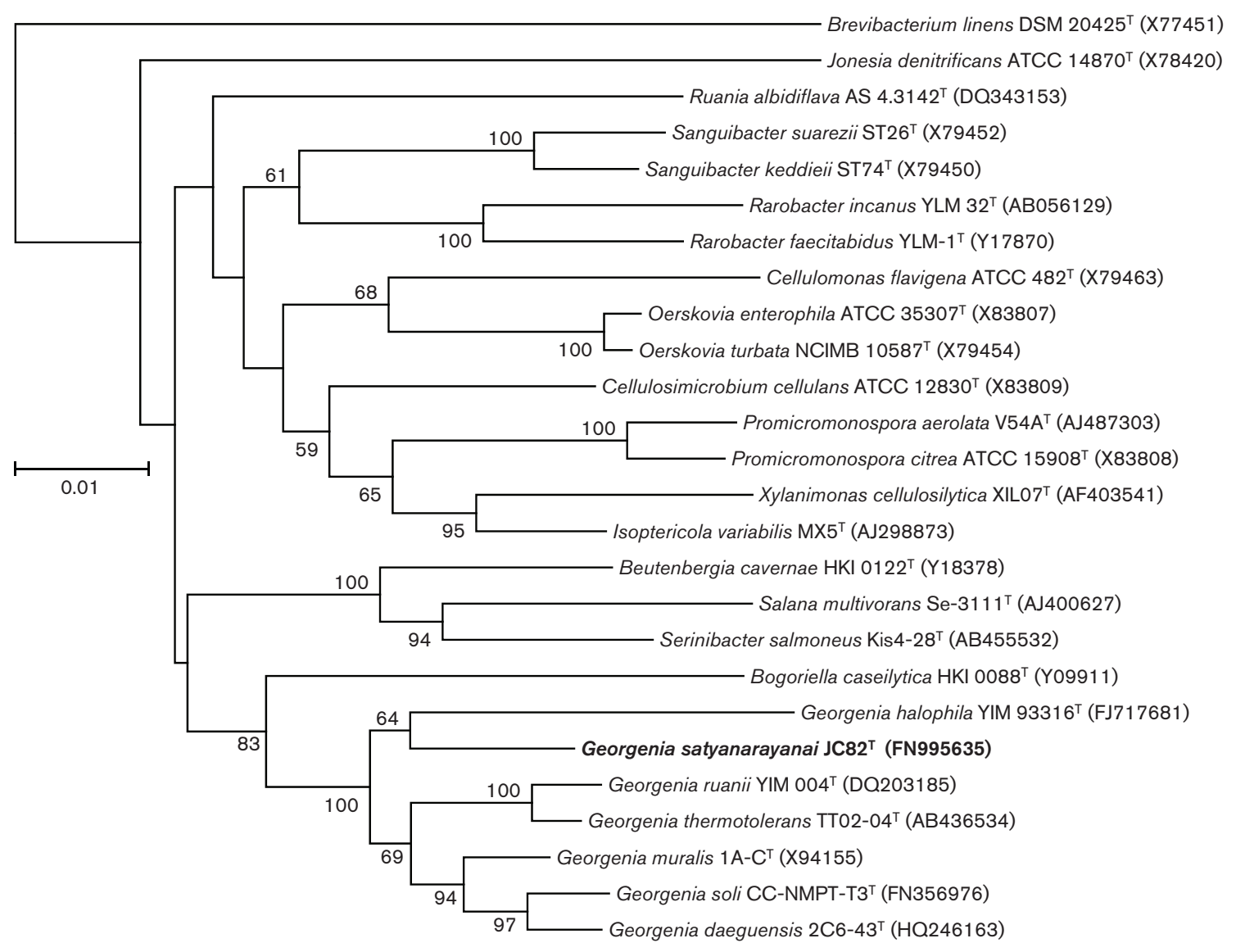

Fig. 1. Phylogenetic analysis based on 16S rRNA gene sequences available from the EMBL database (accession numbers are given in parentheses). Multiple alignments, distance calculations (distance options according to the Kimura two-parameter model) and clustering with the neighbour-joining method were performed by using MEGA software version 4 (Tamura et al., 2007). Bootstrap values (percentage of 500 replications) are shown at the branching points. Bar, 0.01 substitutions per nucleotide position.

for growth but could be tolerated up to $5 \%(\mathrm{w} / \mathrm{v})$, with optimum growth at $2 \% \mathrm{NaCl}$. Optimum growth occurred at $25-37{ }^{\circ} \mathrm{C}$. Casein was not hydrolysed and gelatin was not liquefied. Oxidase, chitinase, lipase and urease activities were negative, but amylase and catalase activities were positive. The absence of oxidase in strain $\mathrm{JC}^{2} 2^{\mathrm{T}}$ differentiated the novel isolate from all other members of the genus Georgenia (Table 1). Amylase activity was optimum at pH $10\left(52.2 \mathrm{U} \mathrm{ml}^{-1}\right.$; Fig. S2a), and at $75{ }^{\circ} \mathrm{C}$ (Fig. S2b). G. muralis $1 \mathrm{~A}-\mathrm{C}^{\mathrm{T}}$ was negative for amylase activity, while G. soli CC-NMPT-T3 ${ }^{\mathrm{T}}$ only had activity at $\mathrm{pH}$ 7-8 (simultaneous comparative assays were performed on starch agar plates).

Strain $\mathrm{JC} 82^{\mathrm{T}}$ was an obligate aerobe and chemoorganoheterotroph. Organic substrates which support growth of strain $\mathrm{JC}^{\mathrm{T}} 2^{\mathrm{T}}$ are given in Table S1. Whole-cell fatty acid analysis of strain $\mathrm{JC}^{\mathrm{T}}{ }^{\mathrm{T}}$ revealed that anteiso- $\mathrm{C}_{15: 0}$ was the predominant fatty acid $(40.9 \%)$, and significant proportions of iso- $\mathrm{C}_{14: 0}(11.5 \%), \mathrm{C}_{14: 0}(11.5 \%), \mathrm{C}_{16: 0}(9.2 \%)$, iso- $\mathrm{C}_{15: 0}(6.6 \%)$ and iso- $\mathrm{C}_{16: 0}(6.3 \%)$ were also detected.
The major quinone of strain $\mathrm{JC}^{2} 2^{\mathrm{T}}$ was menaquinone MK-8 $\left(\mathrm{H}_{4}\right)(98 \%)$. Polar lipids of strain $\mathrm{JC}^{\mathrm{T}}{ }^{\mathrm{T}}$ were diphosphatidylglycerol, phosphatidylglycerol, phosphatidylinositol, phosphatidylinositol mannosides, an unknown lipid (L1) and a glycolipid (GL3) (Fig. S3). An unidentified phospholipid (PL) of G. muralis $1 \mathrm{~A}-\mathrm{C}^{\mathrm{T}}$ (Altenburger et al., 2002) was identified in this study as phosphatidylinositol (PI; Fig. S3), and the major cell wall polar lipids were in concurrence with the genus Georgenia (Li et al., 2007).

The cell-wall amino acids of strain $\mathrm{JC} 82^{\mathrm{T}}$ were L-glutamine, L-alanine, D-alanine and L-lysine, which was similar to the results for G. muralis $1 \mathrm{~A}-\mathrm{C}^{\mathrm{T}}$ and G. soli CC-NMPT-T3 ${ }^{\mathrm{T}}$ (Fig. S4) and is characteristic of the genus Georgenia (peptidoglycan type A4 $\alpha$ based on lysine as diagnostic diamino acid, murein type A11.54). However, strain $\mathrm{JC}^{2} 2^{\mathrm{T}}$ could be differentiated from members of the genus Georgenia based on the absence of oxidase (Table 1). Furthermore, strain $\mathrm{JC}^{\mathrm{T}}{ }^{\mathrm{T}}$ exhibited differences from its closest phylogenetic relatives, G. muralis $1 \mathrm{~A}-\mathrm{C}^{\mathrm{T}}$ and G. soli CC-NMPT-T3 ${ }^{\mathrm{T}}$ by the presence of an unidentified glycolipid (GL3; Table 1), the 
Table 1. Differential characteristics between strain $\mathrm{JC} 82^{\top}$ and two members of the genus Georgenia

Strains: 1 , JC82 ${ }^{\mathrm{T}} ; 2$, G. muralis 1A-C ${ }^{\mathrm{T}} ; 3$, G. soli CC-NMPT-T3 ${ }^{\mathrm{T}}$. All data from this study. All strains were catalase-positive, contained MK-8( $\left.\mathrm{H}_{4}\right)$ as the major quinone, and L-alanine, L-glutamic acid and L-lysine in cell wall peptidoglycan. +, Positive/present; -, negative/absent; DPG, diphosphatidylglycerol; GL1-3, unidentified glycolipids, L1-2, unidentified lipids; PG, phosphatidylglycerol; PI, phosphatidylinositol; PIM, phosphatidylinositol mannosides; PL, unidentified phospholipid; ai, anteiso.

\begin{tabular}{|c|c|c|c|}
\hline Characteristic & 1 & 2 & 3 \\
\hline Cell morphology & Ovoid-rod & Rod-coccus & Cocci \\
\hline Motility & - & - & + \\
\hline $\mathrm{NaCl}$ tolerance range $(\%, \mathrm{w} / \mathrm{v})$ & $0-5$ & $0-7$ & $1-3$ \\
\hline $\mathrm{pH}$ range & $4-12$ & $6-9$ & $6.5-10$ \\
\hline Starch hydrolysis & + & - & + \\
\hline Polar lipids & DPG, PG, PI, PIM, L1, GL3 & DPG, PG, PI, PIM, GL1, L1 & DPG, PG, PI, PIM, GL1-2, L1-2 \\
\hline Major fatty acid(s) & ai- $\mathrm{C}_{15: 0}$ & ai- $\mathrm{C}_{15: 0}$ ai- $\mathrm{C}_{15: 1}$ & ai- $\mathrm{C}_{15: 0}$ ai- $\mathrm{C}_{15: 1}$ \\
\hline DNA G $+\mathrm{C}$ content $(\mathrm{mol} \%)$ & 73.4 & 70.2 & 72 \\
\hline
\end{tabular}

absence of anteiso- $\mathrm{C}_{15: 1}$ fatty acid and the presence of a thermostable alkaline amylase. Strain $\mathrm{JC}^{\mathrm{T}}{ }^{\mathrm{T}}$ differs from $G$. halophila YIM93316 ${ }^{\mathrm{T}}$ in salt tolerance and the absence of an unidentified phospholipid (PL; Tang et al., 2010). Therefore, on the basis of phenotypic and genotypic distinctiveness, strain $\mathrm{JC}^{\mathrm{T}} 2^{\mathrm{T}}$ is considered to represent a novel species of the genus Georgenia, for which the name Georgenia satyanarayanai sp. nov. is proposed.

\section{Description of Georgenia satyanarayanai sp. nov.}

Georgenia satyanarayanai (sa.ty.a.na.ra.ya'na.i. N.L. gen. masc. n. satyanarayanai of Satyanarayana, named in honour of Professor T. Satyanarayana, an eminent microbiologist who significantly contributed to the knowledge of extremophiles from India).

Forms bright yellow colonies on nutrient agar. Cells are ovoid to rod-shaped, $0.8-1.2 \mu \mathrm{m}$ in diameter. Gram-stain-positive, oxidase-negative, catalase-positive, obligate aerobe with chemoorganoheterotrophic growth mode. Good growth occurs after $48 \mathrm{~h}$ of incubation on nutrient agar at $37{ }^{\circ} \mathrm{C}$. Growth occurs at $\mathrm{pH} 4-12$ (optimum, 7-10). $\mathrm{NaCl}$ is not essential for growth, but growth is enhanced in the presence of $\mathrm{NaCl}$ (optimum $2 \%$, tolerated up to $5 \%$ ). Produces thermostable alkaline amylase. Utilizes a wide range of carbon sources (Biolog) including dextrin, glycogen, mannan, amygdalin, Larabinose, cellobiose, $\mathrm{D}$-fructose, $\mathrm{D}$-galactose, gentiobiose, $\mathrm{D}$ gluconic acid, $\alpha$-D-glucose, maltose, maltotriose, D-mannose, D-ribose, salicin, D-sorbitol, trehalose, turanose, D-xylose, glycerol, sucrose, acetic acid, adenosine, 2'-deoxyadenosine, pyruvic acid methyl ester, pyruvic acid, palatinose, inosine and thymidine. D-Galacturonic acid, melezitose, D-tagatose, $\alpha$-ketovaleric acid, lactamide, L-malic acid, succinamic acid, thymidine- 5 '-monophosphate, DL- $\alpha$-glycerol phosphate, 2,3butanediol, D-glucose 6-phosphate and uridine are utilized weakly. The peptidoglycan type is $\mathrm{A} 4 \alpha$, and major quinone is MK-8 $\left(\mathrm{H}_{4}\right)$. Major polar lipids consist of diphosphatidylglycerol, phosphatidylglycerol, phosphatidylinositol and phosphatidylinositol mannosides. An unidentified lipid (L1) and a glycolipid (GL3) are present in moderate amounts. Major $(>5 \%)$ fatty acids are anteiso- $\mathrm{C}_{15: 0}$, iso- $\mathrm{C}_{14: 0}, \mathrm{C}_{14: 0}$, $\mathrm{C}_{16: 0}$, iso- $\mathrm{C}_{15: 0}$ and iso- $\mathrm{C}_{16: 0}$.

The type strain $\mathrm{JC} 82^{\mathrm{T}}\left(=\mathrm{KCTC} 19802^{\mathrm{T}}=\mathrm{NBRC} 107612^{\mathrm{T}}\right.$ ) was isolated from a sediment sample of Lonar Lake, India. The DNA G $+\mathrm{C}$ content of the type strain is $73.4 \mathrm{~mol} \%$.

\section{Acknowledgements}

We thank Professor J. Euzéby for his expert suggestion for correct species epithet and Latin etymology. E. V.V.R. thanks CSIR for SRF fellowship. We thank Dr A. B. Arun, Yenepoya Research Centre, Yenepoya University, Mangalore, India and Dr C.-C. Young, College of Agriculture and Natural Resources, Department of Soil and Environmental Sciences, National Chung Hsing University, Taichung 402, Taiwan, ROC for providing Georgenia soli CC-NMPT-T3 ${ }^{\mathrm{T}}$ for comparative taxonomic analysis.

\section{References}

Altenburger, P., Kämpfer, P., Schumann, P., Vybiral, D., Lubitz, W. \& Busse, H.-J. (2002). Georgenia muralis gen. nov., sp. nov., a novel actinobacterium isolated from a medieval wall painting. Int J Syst Evol Microbiol 52, 875-881.

Altschul, S. F., Gish, W., Miller, W., Myers, E. W. \& Lipman, D. J. (1990). Basic local alignment search tool. J Mol Biol 215, 403-410.

Anil Kumar, P., Srinivas, T. N. R., Madhu, S., Manorama, R. \& Shivaji, S. (2010a). Indibacter alkaliphilus gen. nov., sp. nov., an alkaliphilic bacterium isolated from a haloalkaline lake. Int J Syst Evol Microbiol 60, 721-726.

Anil Kumar, P., Srinivas, T. N. R., Pavan Kumar, P., Madhu, S. \& Shivaji, S. (2010b). Nitritalea halalkaliphila gen. nov., sp. nov., an alkaliphilic bacterium of the family 'Cyclobacteriaceae', phylum Bacteroidetes. Int J Syst Evol Microbiol 60, 2320-2325.

Brosius, J., Palmer, M. L., Kennedy, P. J. \& Noller, H. F. (1978). Complete nucleotide sequence of a $16 \mathrm{~S}$ ribosomal RNA gene from Escherichia coli. Proc Natl Acad Sci U S A 75, 4801-4805.

Cappuccino, J. G. \& Sherman, N. (1998). Microbiology: a Laboratory Manual, 5th edn. California: Benjamin/Cummings Science Publishing. 
Chun, J., Lee, J.-H., Jung, Y., Kim, M., Kim, S., Kim, B. K. \& Lim, Y. W. (2007). EzTaxon: a web-based tool for the identification of prokaryotes based on $16 \mathrm{~S}$ ribosomal RNA gene sequences. Int J Syst Evol Microbiol 57, 2259-2261.

Hiraishi, A. \& Hoshino, Y. (1984). Distribution of rhodoquinone in Rhodospirillaceae and its taxonomic implications. I Gen Appl Microbiol 30, 435-448.

Hiraishi, A., Hoshino, Y. \& Kitamura, H. (1984). Isoprenoid quinone composition in the classification of Rhodospirillaceae. J Gen Appl Microbiol 30, 197-210

Imhoff, J. F. \& Pfennig, N. (2001). Thioflavicoccus mobilis gen. nov., sp. nov., a novel purple sulfur bacterium with bacteriochlorophyll $b$. Int $J$ Syst Evol Microbiol 51, 105-110.

Imhoff, J. F., Süling, J. \& Petri, R. (1998). Phylogenetic relationships among the Chromatiaceae, their taxonomic reclassification and description of the new genera Allochromatium, Halochromatium, Isochromatium, Marichromatium, Thiococcus, Thiohalocapsa and Thermochromatium. Int J Syst Bacteriol 48, 1129-1143.

Joshi, A. A., Kanekar, P. P., Kelkar, A. S., Shouche, Y. S., Vani, A. A., Borgave, S. B. \& Sarnaik, S. S. (2008). Cultivable bacterial diversity of alkaline Lonar Lake, India. Microb Ecol 55, 163-172.

Kates, M. (1972). Techniques of Lipidology. New York: Elsevier.

Kates, M. (1986). Techniques of Lipidology: Isolation, Analysis, and Identification of Lipids. Amsterdam: Elsevier.

Kimura, M. (1980). A simple method for estimating evolutionary rates of base substitutions through comparative studies of nucleotide sequences. J Mol Evol 16, 111-120.

Lane, D. J., Pace, B., Olsen, G. J., Stahl, D. A., Sogin, M. L. \& Pace, N. R. (1985). Rapid determination of $16 \mathrm{~S}$ ribosomal RNA sequences for phylogenetic analyses. Proc Natl Acad Sci U S A 82, 6955-6959.

Li, W.-J., Xu, P., Schumann, P., Zhang, Y.-O., Pukall, R., Xu, L.-H., Stackebrandt, E. \& Jiang, C.-L. (2007). Georgenia ruanii sp. nov., a novel actinobacterium isolated from forest soil in Yunnan (China), and emended description of the genus Georgenia. Int J Syst Evol Microbiol 57, 1424-1428.

Marmur, J. (1961). A procedure for the isolation of deoxyribonucleic acid from micro-organisms. J Mol Biol 3, 208-218.

McKerrow, J., Vagg, S., McKinney, T., Seviour, E. M., Maszenan, A. M., Brooks, P. \& Seviour, R. J. (2000). A simple HPLC method for analysing diaminopimelic acid diastereomers in cell walls of Grampositive bacteria. Lett Appl Microbiol 30, 178-182.

Mesbah, M., Premachandran, U. \& Whitman, W. B. (1989). Precise measurement of the $\mathrm{G}+\mathrm{C}$ content of deoxyribonucleic acid by high-performance liquid chromatography. Int J Syst Bacteriol 39, 159167.

Nelson, N. (1944). A photometric adaptation of the somogyi method for the determination of glucose. J Biol Chem 153, 375-380.

Oren, A., Duker, S. \& Ritter, S. (1996). The polar lipid composition of Walsby's square bacterium. FEMS Microbiol Lett 138, 135-140.

Sanger, F., Nicklen, S. \& Coulson, A. R. (1977). DNA sequencing with chain-terminating inhibitors. Proc Natl Acad Sci U S A 74, 5463-5467.

Sasser, M. (1990). Identification of bacteria by gas chromatography of cellular fatty acids, MIDI Technical Note 101. Newark, DE: MIDI Inc.

Schleifer, K. H. (1985). Analysis of the chemical composition and primary structure of murein. Methods Microbiol 18, 123-156.

Schleifer, K. H. \& Kandler, O. (1972). Peptidoglycan types of bacterial cell walls and their taxonomic implications. Bacteriol Rev 36, 407-477.

Tamura, K., Dudley, J., Nei, M. \& Kumar, S. (2007). MEGA4: molecular evolutionary genetics analysis (MEGA) software version 4.0. Mol Biol Evol 24, 1596-1599.

Tang, S.-K., Wang, Y., Lou, K., Mao, P.-H., Xu, L.-H., Jiang, C.-L., Kim, C.-J. \& Li, W.-J. (2009a). Kocuria halotolerans sp. nov., an actinobacterium isolated from a saline soil in China. Int J Syst Evol Microbiol 59, 1316-1320.

Tang, S.-K., Wang, Y., Chen, Y., Lou, K., Cao, L.-L., Xu, L.-H. \& Li, W.-J. (2009b). Zhihengliuella alba sp. nov., and emended description of the genus Zhihengliuella. Int J Syst Evol Microbiol 59, 2025-2031.

Tang, S.-K., Wang, Y., Lee, J.-C., Lou, K., Park, D.-J., Kim, C.-J. \& Li, W.-J. (2010). Georgenia halophila sp. nov., a halophilic actinobacterium isolated from a salt lake. Int J Syst Evol Microbiol 60, 1317-1421.

Tindall, B. J. (1990a). Lipid composition of Halobacterium lacusprofundi. FEMS Microbiol Lett 66, 199-202.

Tindall, B. J. (1990b). A comparative study of the lipid composition of Halobacterium saccharovorum from various sources. Syst Appl Microbiol $13,128-130$

Tindall, B. J., Rosselló-Móra, R., Busse, H.-J., Ludwig, W. \& Kämpfer, P. (2010). Notes on the characterization of prokaryote strains for taxonomic purposes. Int J Syst Evol Microbiol 60, 249-266.

Wani, A. A., Surakasi, V. P., Siddharth, J., Raghavan, R. G., Patole, M. S., Ranade, D. \& Shouche, Y. S. (2006). Molecular analyses of microbial diversity associated with the Lonar soda lake in India: an impact crater in a basalt area. Res Microbiol 157, 928-937.

Woo, S. G., Cui, Y., Kang, M. S., Jin, L., Kim, K. K., Lee, S.-T., Lee, M. \& Park, J. (2012). Georgenia daeguensis sp. nov., isolated from 4-chlorophenol enrichment culture. Int J Syst Evol Microbiol. 62, 1703-1709. 